\title{
Controlling Disinfection By-Products Formation in Rainwater: Technologies and Trends
}

\author{
Djamel Ghernaout ${ }^{1,2^{*}}$, Noureddine Elboughdiri ${ }^{1,3}$ \\ ${ }^{1}$ Chemical Engineering Department, College of Engineering, University of Ha'il, Ha'il, Saudi Arabia \\ ${ }^{2}$ Chemical Engineering Department, Faculty of Engineering, University of Blida, Blida, Algeria \\ ${ }^{3}$ Département de Génie Chimique de Procédés, Laboratoire Modélisation, Analyse, et Commande des systèmes, Ecole Nationale \\ d’Ingénieurs de Gabès (ENIG), Gabès, Tunisia \\ Email: ^djamel_andalus@hotmail.com
}

How to cite this paper: Ghernaout, D. and Elboughdiri, N. (2020) Controlling Disinfection By-Products Formation in Rainwater: Technologies and Trends. Open Access Library Journal, 7: e6162. https://doi.org/10.4236/oalib.1106162

Received: February 13, 2020

Accepted: March 20, 2020

Published: March 23, 2020

Copyright $\odot 2020$ by author(s) and Open Access Library Inc.

This work is licensed under the Creative Commons Attribution International License (CC BY 4.0).

http://creativecommons.org/licenses/by/4.0/

(c) (i) Open Access

\begin{abstract}
With an augmenting lack of pure water, rainwater has been viewed as an invaluable substitutional potable water fountain. The methods implemented for rainwater treatment are in control of the safety of potable water. Researchers examined various disinfection methods to estimate the monitoring of disinfection by-products (DBPs) generation. The tried disinfection techniques involved chlorination and chloramination, pre-oxidation by potassium permanganate $\left(\mathrm{KMnO}_{4}\right)$ and potassium ferrate $\left(\mathrm{K}_{2} \mathrm{FeO}_{4}\right)$, ultraviolet/hydrogen peroxide $\left(\mathrm{UV} / \mathrm{H}_{2} \mathrm{O}_{2}\right)$, and ultraviolet/persulfate (UV/PS) methods. In spite of low contaminants existing in rainwater comparatively with surface water, the same findings are mostly obtained in terms of DBPs production and control procedures using the above-mentioned technologies. Employing granular activated carbon post-treatment could greatly reduce the concentrations and poisonous effects of DBPs. Moreover, secure multi-barrier techniques, like distillation and membrane processes, remain to be suggested, tested and industrially encouraged.
\end{abstract}

\section{Subject Areas \\ Environmental Sciences}

\section{Keywords}

Rainwater Harvesting (RWH), Disinfection by-Products (DBPs), Chlor(am)ination, Pre-Oxidation Ultraviolet Related Advanced Oxidation Process (UV-Related AOP), Membrane Processes, Water Treatment 


\section{Introduction}

With the expansion of uncontrolled industrial and agricultural activities, natural water is subjected to huge pollution by wastewater effluents carrying nutrients, organic matter (OM) (like petroleum hydrocarbons, pharmaceuticals, pesticides, and herbicides), heavy metals, etc. [1] [2]. The increase in population and enhancement of living standards lead to a large request for freshwater [3]-[7]. In order to lessen the gap between supply and request of water, rainwater has been harvested for drinking and non-drinking usage (like irrigation, and washing toilet) [8] [9]. Household collection systems have been promoted by the government in Australia with $23 \%$ of residents in South Australia employing rainwater as a potable water source [10] [11]. In Vietnam, freshwater lack accredited to heavy metal contamination may as well be relieved via rainwater harvesting ( $\mathrm{RWH}$ ) [12]. A project applied by the Women's Development Foundation in China called for the building of water cellars and water supply facilities to solve the issue of freshwater lack [13]. Up to 2009, around 1.6 million people in 23 provinces profited from this project [10]. Shortly, gathering and using rainwater have beginning to be the hotspot in the world [14]. In addition, researchers [14] [15] have proved that the gathered rainwater is usually polluted by either chemical or microbiological contamination, which may constitute dangers to human and domestic animal health (Figure 1). Further, scientists [16] as well noted that the properties

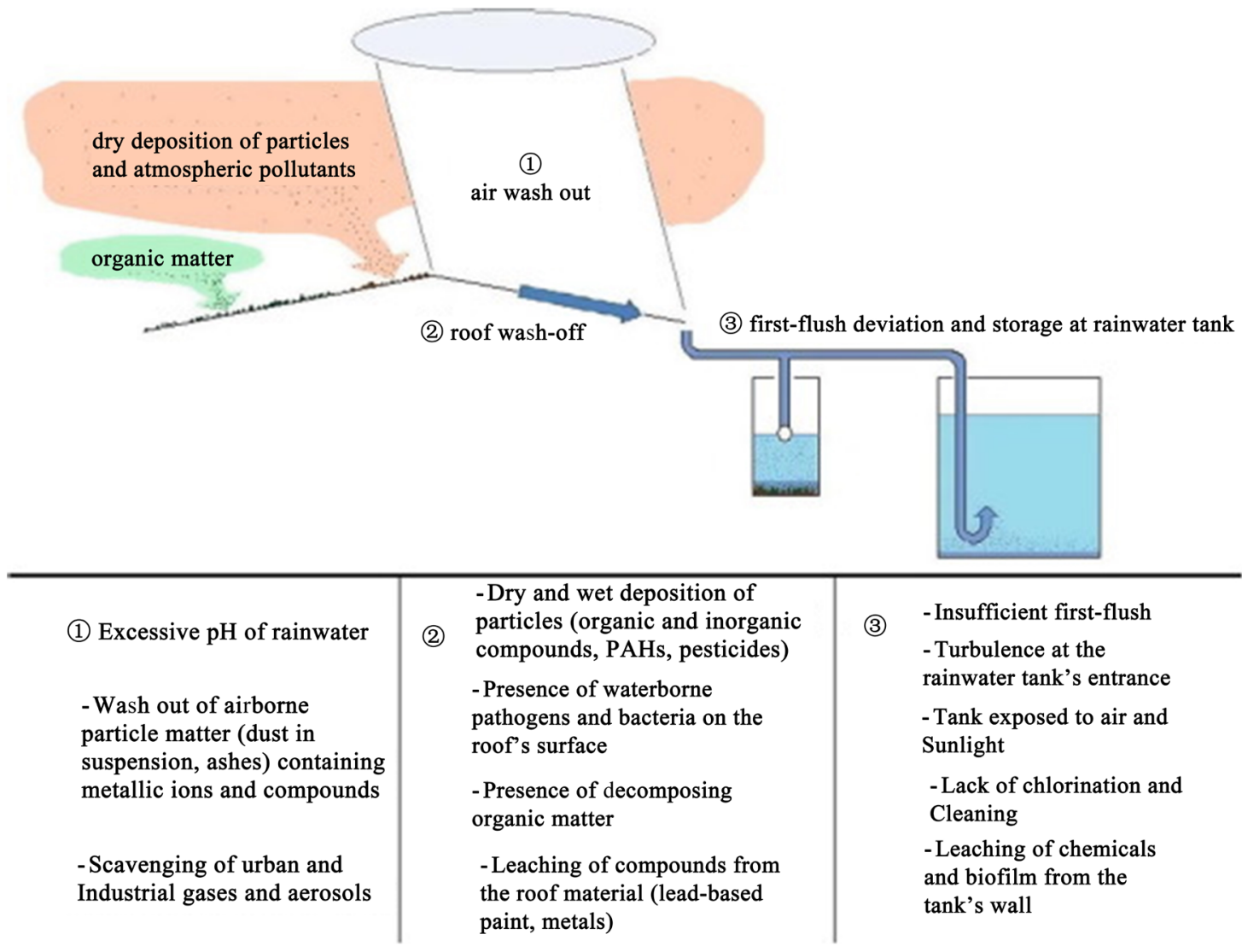

Figure 1. Three main steps in rainwater contamination as suggested by Sánchez et al. [14]. 
of rainwater could be vastly distinct from that in raw water. Even if rainwater usage is a general tendency, relating researches focusing on rainwater analyzing and ameliorating for secure reuse are rare. Consequently, more care has to be accorded to the treatment methods of rainwater to not only furnish pure and secure water to the people but as well reduce the knowledge vacuum aforesaid.

Disinfection remains an important treatment method to avert diseases provoked by pathogens existing in the water [17] [18] [19] [20] [21]. Chlorine stays the most frequent disinfectant, which is usually utilized in drinking water treatment plants [22]-[27]. Sad to say, chlorine may as well oxidize natural organic matter (NOM) [28] [29] in water and produce unwanted disinfection by-products (DBPs), which may form chronic cyto- and genotoxicity [30] [31] [32] [33] [34]. Juxtaposed with chlorine, monochloramine $\left(\mathrm{NH}_{2} \mathrm{Cl}\right)$ is frequently employed as a substitutional killing agent and manifests supremacy in furnishing longer-lasting remaining chlorine in the distribution system [35]. Nevertheless, $\mathrm{NH}_{2} \mathrm{Cl}$ may as well augment the generation of nitrogenous DBPs (N-DBPs), which depict much more elevated poisoning than usual carbonaceous DBPs (C-DBPs) [36] [37]. Since the 1970s, investigations concerning the production of DBPs throughout the disinfection of potable water were thriving [12] [13] [15] [16] [31] [38], during the time that the corresponding researches on rainwater are seldom published. Even if the makeup of rainwater is touched via diverse variables [32] [33], several usual DBPs are in fact formed throughout the disinfection technique. Following a fresh investigation [33], seven chlorinated DBPs (trichloromethane (TCM), dichloroacetic acid (DCAA), trichloroacetic acid (TCAA), chloral hydrate $(\mathrm{CH})$, dichloroacetonitrile (DCAN), trichloronitromethane (TCNM), and dichloroacetamide (DCAM)) are the most produced DBP species throughout rainwater chlorination and the arrangement of importance of DBP yields in rainwater is identical as those generated in surface water. Consequently, it is crucial to assess and dominate the production of DBPs in rainwater throughout the disinfection method. Assuming that the microorganisms carried in rainwater may be efficaciously demobilized at a small injection of chlorine (2 $\left.\mathrm{mg}^{-\mathrm{Cl}} 2 / \mathrm{L}\right)$ [34], dominating DBP generation in rainwater has to be seen as the first target with a view to guarantee the secure supply and use of rainwater. Nevertheless, the data aforesaid were restricted, which is the objective of Liu et al. [1] investigation.

Eliminating DBP precursors via employing substitutional treatments (like preoxidation and advanced oxidation processes (AOPs)) [39] [40] [41] prior disinfection has been investigated and noted to be efficient in dominating the production of DBPs [35] [38] [42] [43]. As one of the strong oxidants, potassium permanganate $\left(\mathrm{KMnO}_{4}\right)$ has been viewed as a substitutional pre-oxidant, which may remove the taste and odor issues and alleviate the trihalomethane (THM) generation [44]. Potassium ferrate $\left(\mathrm{K}_{2} \mathrm{FeO}_{4}\right)$ is one more powerful oxidant both in acid and basic circumstances [45] [46] [47]. Numerous researches have proved that $\mathrm{K}_{2} \mathrm{FeO}_{4}$ is a better oxidant for water treatment [48]. As an environmentally friendly treatment technique, ultraviolet (UV) irradiation possesses the huge ca- 
pacity to demobilize Cryptosporidium and pathogenic microbes [49] and oxidize $\mathrm{OM}$ [1]. In addition, UV-related AOPs, like UV/hydrogen peroxide $\left(\mathrm{UV} / \mathrm{H}_{2} \mathrm{O}_{2}\right)$ and UV/persulfate (UV/PS), displayed an outstanding capacity to decompose pollutants in water via forming highly reactive oxidizing species (like sulfate radical $\left(\mathrm{SO}_{4}{ }^{-{ }^{-}}\right)$and hydroxyl radical $\left({ }^{\circ} \mathrm{OH}\right)$ ] [38] [50] [51] [52]. Moreover, the oxidation potential of $\mathrm{SO}_{4}{ }^{\bullet-}\left(E_{0}=2.5-3.1 \mathrm{~V}\right)$ is slightly more powerful than that of ${ }^{\bullet} \mathrm{OH}$ $\left(E_{0}=1.9-2.7 \mathrm{~V}\right)$ and is more efficient in oxidizing organic chemicals with carbon-carbon double bonds and benzene rings [53]. Up to now, even if DBP yields from the precursors in raw water throughout diverse pre-treatment techniques have been examined [16] [38] [42], no data mentioned the DBP production in rainwater throughout different pre-oxidation methods and AOPs. Consequently, it is required to deeply understand such problems, which will give an important foundation for appropriate treatment and use of rainwater.

\section{Diverse Disinfection Techniques for Controlling DBPs Production in Rainwater}

Liu et al. [1] consistently juxtaposed diverse disinfection techniques to estimate the control of DBPs generation and integrated cyto- and genotoxicity of the treated rainwater. The assessed disinfection methods involved chlorination and chloramination, pre-oxidation by $\mathrm{KMnO}_{4}$ and $\mathrm{K}_{2} \mathrm{FeO}_{4}$, ultraviolet/hydrogen peroxide $\left(\mathrm{UV} / \mathrm{H}_{2} \mathrm{O}_{2}\right)$, and ultraviolet/persulfate (UV/PS) techniques. Their findings depicted that chloramination was efficient in dominating the production of C-DBPs; however, not N-DBPs. Juxtaposed to $\mathrm{KMnO}_{4}$ pre-oxidation, better removal of nearly all DBPs was noted throughout $\mathrm{K}_{2} \mathrm{FeO}_{4}$ pre-oxidation. Following the estimation of cytotoxicity index and genotoxicity index, cyto- and genotoxicity of the samples diminished clearly at the injection of $\geq 2.0 \mathrm{mg} / \mathrm{L} \mathrm{KMnO}_{4}$ and $\mathrm{K}_{2} \mathrm{FeO}_{4}$. Controlling the cyto- and genotoxicity of the generated DBPs from the two UV-related AOPs was more efficacious at the injection of $\geq 1.0 \mathrm{mM}$ PS and $\geq 5.0$ $\mathrm{mM} \mathrm{H}_{2} \mathrm{O}_{2}$. Further, UV/PS was much strongest to modify the structure of DBP precursors in rainwater.

\section{Investigating the Microbial Faction in Rainwater Collected from Various Roofing Materials}

Bae et al. [54] examined the effect of roofing material on the microbial feature of rainwater newly collected from pilot-scale roofs (concrete tile, cool, green, Galvalume $^{\circledR}$ metal, and asphalt fiberglass shingle). The microbial feature of newly collected rainwater from six rain events during two years was assessed via highthroughput sequencing and culture-dependent and -independent procedures. The levels of total coliform were importantly diverse between rainwaters gathered from the different roofing materials ( $\mathrm{p}$-value $>0.05$ ). Nevertheless, the fecal coliform levels and the copy numbers of Enterococcus $23 \mathrm{~S}$ rRNA genes and total Bacteria 16S rRNA genes did not change by type of roofing material in a statistically considerable manner. Potential human pathogenic microorganisms like Le- 
gionella, Escherichia coli O157:H7, Shiga-toxin-producing E. coli, and adenovirus were found at least once in rainwater collected from the diverse roofing materials, even if the lowest presence of those potential human pathogens was observed from the metal roof. Further, an important change in the microbial factions from the diverse roofing materials was noted at the family and genus levels. Such findings establish that the type of roofing material touches the microbial characteristic of newly collected rainwater, showing that the selection of roofing material may condition the microbial faction composition entering a rainwater storage reservoir. Considering that the detection of possible microorganisms in the newly collected rainwater as well varied among roofing materials, the type of roofing utilized to capture rainwater needs to be taken into account in RWH system design, specifically if the water is intended for drinking usage.

\section{Metal Membrane for Rainwater Use: Filtration Features and Membrane Fouling}

Kim et al. [55] designed and improved a filtration technique employing a metal membrane for efficacious and secure usage of rainwater. The treatment setup is composed of a feed tank carrying rainwater and a metal membrane [56] [57] [58] submerged into the tank. Trials were realized to juxtapose the filtration features of rainwater in a storage tank, roof runoff, and roof garden runoff. Ozone bubbling, as well as aeration in the feed side, was considered to diminish membrane fouling [59] [60] [61] and demobilize microbes. Metal membranes seem to be appropriate to clarify rainwater thanks to their elevated treatment performance of pathogens and solids. Nevertheless, the filterability greatly relied on the rainwater sources, the nominal pore size of the filter, filtration parameters, and operation mode. The main fouling mechanism for the metal membrane filtration was pore blockage.

\section{Prices Related to a Residential Rainwater Harvesting (RWH) Setup}

Wurthmann [62] assessed the eventuality of a largely-deployed residential RWH setup for decreasing demands and supplementing existing, centralized water supply setups in a heavily populated area in Southeast Florida. The estimation used a unique integration of models and approaches, which are portable and usable in different situations and comprise: a nonparametric bootstrapping model for synthetically generating multiple realizations of regional rainfall, water supply and demand, and storage size and reliability outcomes; and an approach for determining expected water and energy savings and costs associated with the RWH system (Figure 2). Results propose that an RWH setup designed to satisfy the outdoor irrigation demands of detached homes in Florida's Broward and Palm Beach Counties could satisfy $54 \%$ of the total additional water demand created by the growing population in this region. This is importantly bigger than the percentages of demand that could be satisfied by numerous suggested centralized procedures 


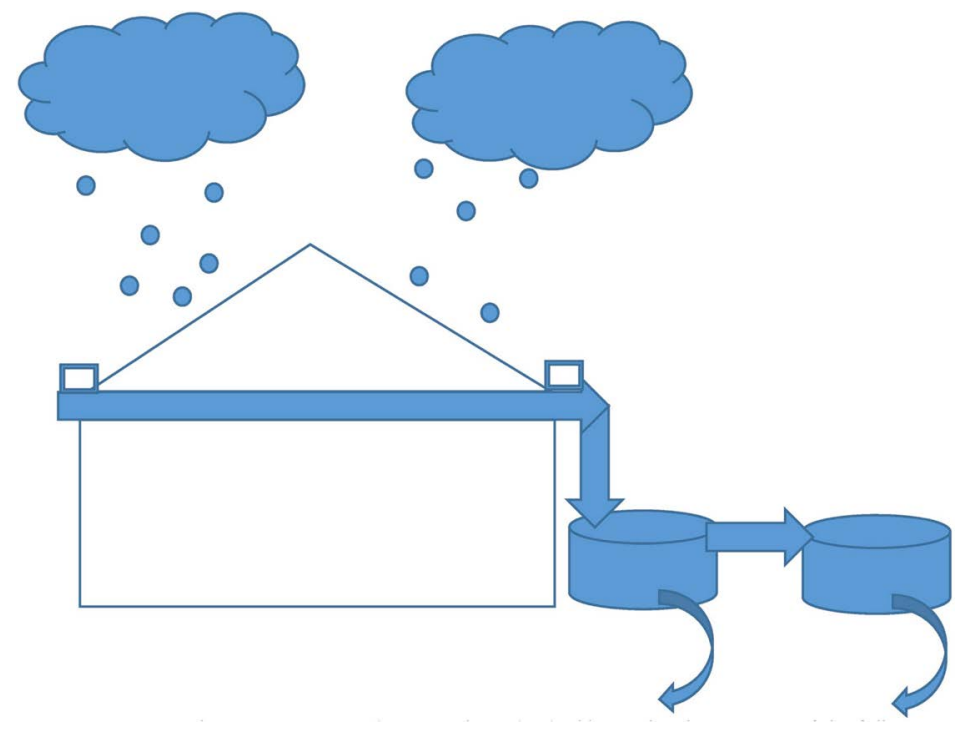

Figure 2. Rainwater harvesting (RWH) system design at the individual house level, consisting of the following elements: house roof as the catchment area; house gutters and downspouts are equipped with debris screens for pretreatment of the rainwater and serve as the conveyance system to move the water from the roof surface to the storage; additional conveyance links between the storage cisterns; aboveground plastic cisterns, which are equipped with fine filters to remove dissolved and suspended solids from the water; water disinfection through chlorination to levels appropriate for treating stored rainwater for irrigation purposes; distribution and irrigation by gravity and drip tubing [62].

to water supply employing groundwater recharge by reclaimed water, comparable to the percentage of demand that could be met by desalinating brackish water from the Floridian Aquifer, but less than the percentage of demand that could be met by a proposed new reservoir and canal system for groundwater recharge. The results as well propose that the expected price of water provided by the decentralized RWH system, which involves considerable savings in energy needs and costs, would be significantly less than the expected costs of water provided by all centralized water supply system alternatives considered, with the exception of the reservoir and canal system.

\section{Evaluating Water Quality of First-Flush Roof Runoff and Harvested Rainwater}

Six pilot RWH setups were installed in five urban, suburban and rural houses, and on a university campus [63]. The setups (Figure 3) are composed of horizontal gutters to collect roof drainage and downdrains which end into one or two plastic storage tanks. Devices were also provided to remove first-flush water. Water quality was monitored in the storage tanks and the first-flush devices during the 2-year period. Water samples were collected at a frequency of once every 10 days, and analyzed according to potable water specifications to determine major anions (such as $\mathrm{SO}_{4}^{2-}, \mathrm{NO}_{3}^{-}, \mathrm{NO}_{2}^{-}, \mathrm{F}^{-}, \mathrm{Cl}^{-}$) and cations (like $\mathrm{NH}_{4}^{+}$, $\mathrm{Na}^{+}, \mathrm{K}^{+}, \mathrm{Ca}^{2+}, \mathrm{Mg}^{2+}$ ), total suspended solids, alkalinity, total phosphorus and microbiological indicators (like total coliforms, E. coli, Streptococcus, Clostridium 


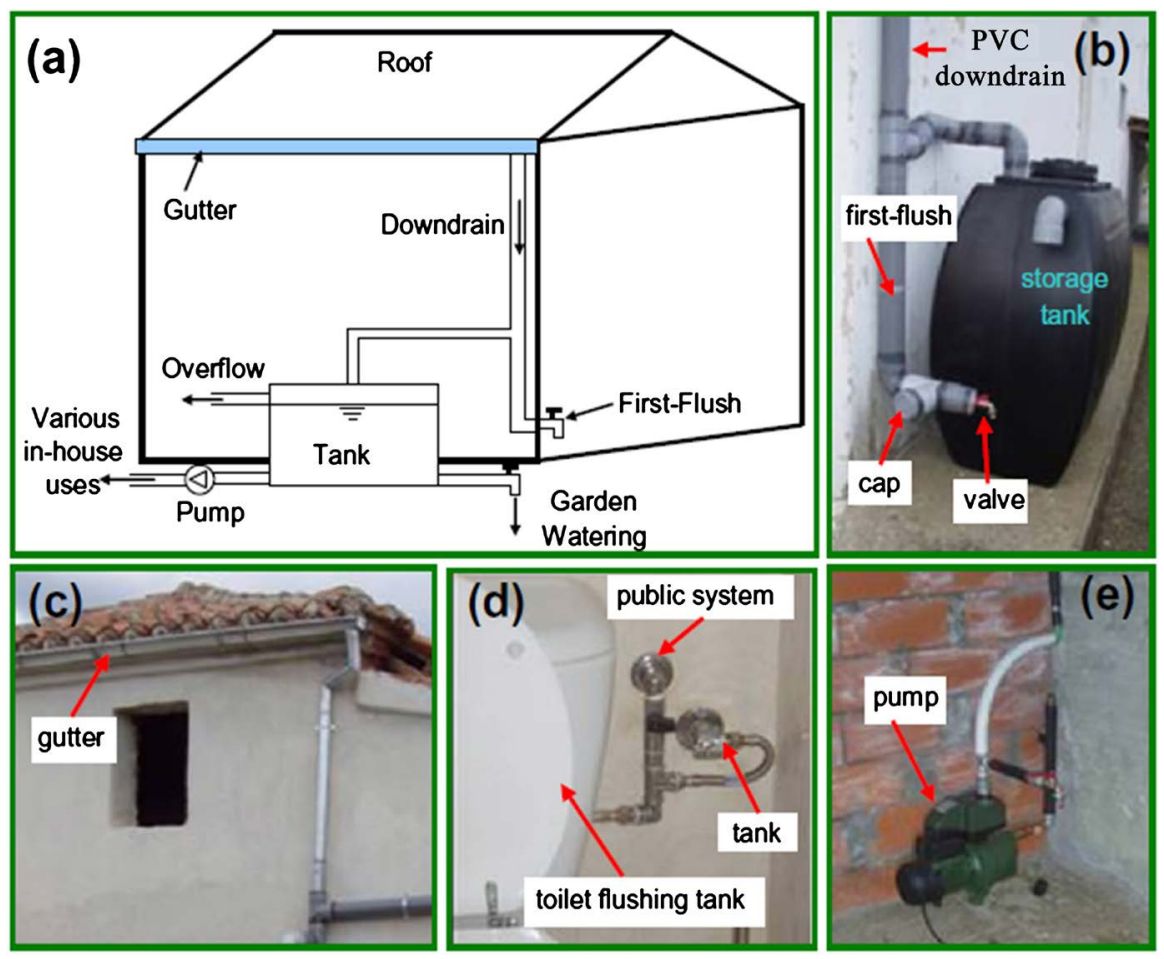

Figure 3. RWH system: (a) schematic diagram of the pilot RWH system; (b) storage tank and first-flush diversion system; (c) gutter and downdrain; (d) dual connection from public water supply and storage tank to toilet flushing tank; (e) pump [63].

perfrigens, Pseudomonas syringae and total viable counts at $22^{\circ} \mathrm{C}$ and $37^{\circ} \mathrm{C}$ ). In addition, temperature, $\mathrm{pH}$, dissolved oxygen and electrical conductivity were measured in situ. The mean levels of chemical parameters in harvested rainwater (with the exception of $\mathrm{NH}_{4}^{+}$) were below the limits set by the 98/93/EU directive for drinking water. Total coliforms were detected in $84.4 \%-95.8 \%$ of the collected rainwater samples in the six tanks. E. coli, Streptococcus, C. perfrigens, $P$. syringae and total viable counts at $22^{\circ} \mathrm{C}$ and $37^{\circ} \mathrm{C}$ were found at low counts in samples of collected rainwater. The collected rainwater quality was found satisfactory regarding its physicochemical parameters, but not regarding its sanitary quality. Therefore, RWH systems in this area could only supply water appropriate for use as gray water.

Similar investigation was performed by [64], and similar results are obtained.

\section{Conclusions}

From this work, the following conclusions can be drawn:

1) Mounting attention throughout the world for securing water resources has conducted to diverse trials to employ rainwater. Rainwater usage furnishes a potential water supply in urban areas and buffers extreme runoff situations in the watercourses. Nevertheless, rainwater in the urban area carries considerable quantities of pollutants comprising solids, microbes, heavy metals, and OM and cannot be utilized without appropriate treatment.

2) The methods implemented for rainwater treatment are in control of the 
safety of potable water. Researchers [1] examined various disinfection methods to estimate the monitoring of disinfection by-products (DBPs) generation. The tried disinfection techniques involved chlorination and chloramination, pre-oxidation by potassium permanganate $\left(\mathrm{KMnO}_{4}\right)$ and potassium ferrate $\left(\mathrm{K}_{2} \mathrm{FeO}_{4}\right)$, ultraviolet/hydrogen peroxide $\left(\mathrm{UV} / \mathrm{H}_{2} \mathrm{O}_{2}\right)$, and ultraviolet/persulfate (UV/PS) methods. In spite of low contaminants existing in rainwater comparatively with surface water, the same findings are mostly obtained in terms of DBPs production and control procedures using the above-mentioned technologies.

3) Employing granular activated carbon post-treatment could greatly reduce the concentrations and poisonous effects of DBPs. Moreover, secure multi-barrier techniques, like distillation and membrane processes, remain to be suggested, tested and industrially encouraged.

\section{Conflicts of Interest}

The authors declare no conflicts of interest regarding the publication of this paper.

\section{References}

[1] Liu, Z., Lin, Y.-L., Chu, W.-H., Xu, B., Zhang, T.-Y., Hu, C.-Y., Cao, T.-C., Gao, N.-Y. and Dong, C.-D. (2020) Comparison of Different Disinfection Processes for Controlling Disinfection by-Product Formation in Rainwater. Journal of Hazardous Materials, 385, Article ID: 121618. https://doi.org/10.1016/j.jhazmat.2019.121618

[2] Ghernaout, D. (2017) Environmental Principles in the Holy Koran and the Sayings of the Prophet Muhammad. American Journal of Environmental Protection, 6, 75-79. https://doi.org/10.11648/j.ajep.20170603.13

[3] Ghernaout, D., Ghernaout, B. and Naceur, M.W. (2011) Embodying the Chemical Water Treatment in the Green Chemistry: A Review. Desalination, 271, 1-10. https://doi.org/10.1016/j.desal.2011.01.032

[4] Ghernaout, D. and Ghernaout, B. (2012) On the Concept of the Future Drinking Water Treatment Plant: Algae Harvesting from the Algal Biomass for Biodiesel Production: A Review. Desalination and Water Treatment, 49, 1-18. https://doi.org/10.1080/19443994.2012.708191

[5] Ghernaout, D., Badis, A., Braikia, G., Matâam, N., Fekhar, M., Ghernaout, B. and Boucherit, A. (2017) Enhanced Coagulation for Algae Removal in a Typical Algeria Water Treatment Plant. Environmental Engineering and Management Journal, 16, 2303-2315. https://doi.org/10.30638/eemj.2017.238

[6] Ghernaout, D. (2018) Magnetic Field Generation in the Water Treatment Perspectives: An Overview. International Journal of Advances in Applied Sciences, 5, 193-203. https://doi.org/10.21833/ijaas.2018.01.025

[7] Ghernaout, D., Aichouni, M. and Alghamdi, A. (2018) Applying Big Data (BD) in Water Treatment Industry: A New Era of Advance. International Journal of Advances in Applied Sciences, 5, 89-97. https://doi.org/10.21833/ijaas.2018.03.013

[8] Simmons, G., Jury, S., Thornley, C., Harte, D., Mohiuddin, J. and Taylor, M. (2008) A Legionnaires' Disease Outbreak: A Water Blaster and Roof-Collected Rainwater Systems. Water Research, 42, 1449-1458. https://doi.org/10.1016/j.watres.2007.10.016

[9] Faragò, M., Brudler, S., Godskesen, B. and Rygaard, M. (2019) An Eco-Efficiency 
Evaluation of Community-Scale Rainwater and Stormwater Harvesting in Aarhus, Denmark. Journal of Cleaner Production, 219, 601-612. https://doi.org/10.1016/j.jclepro.2019.01.265

[10] Plewa, M.J., Wagner, E.D., Muellner, M.G., Hsu, K.M. and Richardson, S.D. (2007) Comparative Mammalian Cell Toxicity of N-DBPs and C-DBPs. In: ACS Symposium Series, Chapter 3, Oxford University Press, Oxford, 36-50. https://doi.org/10.1021/bk-2008-0995.ch003

[11] Ahmed, W., Staley, C., Hamilton, K.A., Beale, D.J., Sadowsky, M.J., Toze, S. and Haas, C.N. (2017) Amplicon-Based Taxonomic Characterization of Bacteria in Urban and Peri-Urban Roof-Harvested Rainwater Stored in Tanks. Science of the Total Environment, 576, 326-334. https://doi.org/10.1016/j.scitotenv.2016.10.090

[12] Weinberg, H.S., Krasner, S.W., Richardson, S.D. and Thruston Jr., A.D. (2002) The Occurrence of Disinfection by-Products (DBPs) of Health Concern in Drinking Water: Results of a Nationwide DBP Occurrence Study. U.S. Environmental Protection Agency, Washington DC, EPA/600/R-02/068 (NTIS PB2003-106823). https://cfpub.epa.gov/si/si_public_record_report.cfm?Lab=NERL\&dirEntryId=63413

[13] Liu, Z., Lin, Y.L., Xu, B., Hu, C.Y., Wang, A.Q., Gao, Z.C., Xia, S.J. and Gao, N.Y. (2018) Formation of Iodinated Trihalomethanes during Breakpoint Chlorination of Iodide-Containing Water. Journal of Hazardous Materials, 353, 505-513. https://doi.org/10.1016/j.jhazmat.2018.04.009

[14] Sánchez, A.S., Cohim, E. and Kalid, R.A. (2015) A Review on Physicochemical and Microbiological Contamination of Roof-Harvested Rainwater in Urban Areas. Sustainability of Water Quality and Ecology, 6, 119-137. https://doi.org/10.1016/j.swaqe.2015.04.002

[15] Zhang, M.S., Xu, B., Wang, Z., Ye, T. and Gao, N.Y. (2016) Formation of Iodinated Trihalomethanes after Ferrate Pre-Oxidation during Chlorination and Chloramination of Iodide-Containing Water. Journal of the Taiwan Institute of Chemical Engineers, 60, 453-459. https://doi.org/10.1016/j.jtice.2015.11.007

[16] Zhou, X.R., Lin, Y.L., Zhang, T.Y., Xu, B., Chu, W.H., Cao, T.C. and Zhu, W.Q. (2019) Speciation and Seasonal Variation of Various Disinfection by-Products in a Full-Scale Drinking Water Treatment Plant in East China. Water Science and Technology-Water Supply, 19, 1579-1586. https://doi.org/10.2166/ws.2019.026

[17] Ghernaout, D. and Ghernaout, B. (2010) From Chemical Disinfection to Electrodisinfection: The Obligatory Itinerary? Desalination and Water Treatment, 16, 156-175. https://doi.org/10.5004/dwt.2010.1085

[18] Ghernaout, D. (2017) Microorganisms' Electrochemical Disinfection Phenomena. EC Microbiology, 9, 160-169.

[19] Ghernaout, D. (2018) Disinfection and DBPs Removal in Drinking Water Treatment: A Perspective for a Green Technology. International Journal of Advances in Applied Sciences, 5, 108-117. https://doi.org/10.21833/ijaas.2018.02.018

[20] Ghernaout, D., Touahmia, M. and Aichouni, M. (2019) Disinfecting Water: Electrocoagulation as an Efficient Process. Applied Engineering, 3, 1-12.

[21] O’Shea, M.L. and Field, R. (1992) An Evaluation of Bacterial Standards and Disinfection Practices Used for the Assessment and Treatment of Stormwater. In: Advances in Applied Microbiology, Volume 37, Academic Press Inc., New York, 21-40. https://doi.org/10.1016/S0065-2164(08)70251-X

[22] Ghernaout, D. and Elboughdiri, N. (2020) Is Not It Time to Stop Using Chlorine for Treating Water? Open Access Library Journal, 7, e6007.

[23] Ghernaout, D., Moulay, S., Ait Messaoudene, N., Aichouni, M., Naceur, M.W. and Boucherit, A. (2014) Coagulation and Chlorination of NOM and Algae in Water 
Treatment: A Review. International Journal of Environmental Monitoring and Analysis, 2, 23-34. https://doi.org/10.11648/j.ijema.s.2014020601.14

[24] Ghernaout, D. (2017) Water Treatment Chlorination: An Updated Mechanistic Insight Review. Chemistry Research Journal, 2, 125-138.

[25] Ghernaout, D., Alghamdi, A., Aichouni, M. and Touahmia, M. (2018) The Lethal Water Tri-Therapy: Chlorine, Alum, and Polyelectrolyte. World Journal of Applied Chemistry, 3, 65-71. https://doi.org/10.11648/j.wjac.20180302.14

[26] Alshammari, Y., Ghernaout, D., Aichouni, M. and Touahmia, M. (2018) Improving Operational Procedures in Riyadh's (Saudi Arabia) Water Treatment Plants Using Quality Tools. Applied Engineering, 2, 60-71.

[27] Ghernaout, D. (2019) Greening Cold Fusion as an Energy Source for Water Treatment Distillation: A Perspective. American Journal of Quantum Chemistry and Molecular Spectroscopy, 3, 1-5.

[28] Ghernaout, D., Naceur, M.W. and Ghernaout, B. (2011) A Review of Electrocoagulation as a Promising Coagulation Process for Improved Organic and Inorganic Matters Removal by Electrophoresis and Electroflotation. Desalination and Water Treatment, 28, 287-320. https://doi.org/10.5004/dwt.2011.1493

[29] Ghernaout, D., Ghernaout, B. and Kellil, A. (2009) Natural Organic Matter Removal and Enhanced Coagulation as a Link between Coagulation and Electrocoagulation. Desalination and Water Treatment, 2, 203-222.

https://doi.org/10.5004/dwt.2009.116

[30] Ghernaout, D. and Elboughdiri, N. (2020) Strategies for Reducing Disinfection by-Products Formation during Electrocoagulation. Open Access Library Journal, 7, e6076. https://doi.org/10.4236/oalib.1106076

[31] Wang, J.Y., Sui, M.H., Yuan, B.J., Li, H.W. and Lu, H.T. (2019) Inactivation of Two Mycobacteria by Free Chlorine: Effectiveness, Influencing Factors, and Mechanisms. Science of the Total Environment, 648, 271-284. https://doi.org/10.1016/j.scitotenv.2018.07.451

[32] Hu, J.L., Chu, W.H., Sui, M.H., Xu, B., Gao, N.Y. and Ding, S.K. (2018) Comparison of Drinking Water Treatment Processes Combinations for the Minimization of Subsequent Disinfection by-Products Formation during Chlorination and Chloramination. Chemical Engineering Journal, 335, 352-361. https://doi.org/10.1016/j.cej.2017.10.144

[33] Chu, W.H., Gao, N.Y., Yin, D.Q., Krasner, S.W. and Mitch, W.A. (2014) Impact of $\mathrm{UV} / \mathrm{H}_{2} \mathrm{O}_{2}$ Pre-Oxidation on the Formation of Haloacetamides and Other Nitrogenous Disinfection Byproducts during Chlorination. Environmental Science \& Technology, 48, 12190-12198. https://doi.org/10.1021/es502115x

[34] Chu, W.H., Li, D.M., Deng, Y., Gao, N.Y., Zhang, Y.S. and Zhu, Y.P. (2016) Effects of UV/PS and UV/ $\mathrm{H}_{2} \mathrm{O}_{2}$ Pre Oxidations on the Formation of Trihalomethanes and Haloacetonitriles during Chlorination and Chloramination of Free Amino Acids and Short Oligopeptides. Chemical Engineering Journal, 301, 65-72.

https://doi.org/10.1016/j.cej.2016.04.003

[35] Hua, G. and Reckhow, D. (2008) DBP Formation during Chlorination and Chloramination: Effect of Reaction Time, pH, Dosage, and Temperature. Journal of the American Water Works Association, 100, 82-89. https://doi.org/10.1002/j.1551-8833.2008.tb09702.x

[36] Ghernaout, D., Naceur, M.W. and Aouabed, A. (2011) On the Dependence of Chlorine by-Products Generated Species Formation of the Electrode Material and Applied Charge during Electrochemical Water Treatment. Desalination, 270, 9-22. 
https://doi.org/10.1016/j.desal.2011.01.010

[37] Boucherit, A., Moulay, S., Ghernaout, D., Al-Ghonamy, A.I., Ghernaout, B., Naceur, M.W., Ait Messaoudene, N., Aichouni, M., Mahjoubi, A.A. and Elboughdiri, N.A. (2015) New Trends in Disinfection by-Products Formation upon Water Treatment. Journal of Research \& Developments in Chemistry, 1-27. https://doi.org/10.5171/2015.628833

[38] Zhang, T.Y., Hu, Y.R., Jiang, L., Yao, S.J., Lin, K.F., Zhou, Y.B. and Cui, C.Z. (2019) Removal of Antibiotic Resistance Genes and Control of Horizontal Transfer Risk by UV, Chlorination and UV/Chlorination Treatments of Drinking Water. Chemical Engineering Journal, 358, 589-597. https://doi.org/10.1016/j.cej.2018.09.218

[39] Ghernaout, D. (2013) Advanced Oxidation Phenomena in Electrocoagulation Process: A Myth or a Reality? Desalination and Water Treatment, 51, 7536-7554. https://doi.org/10.1080/19443994.2013.792520

[40] Ghernaout, D. (2019) Virus Removal by Electrocoagulation and Electrooxidation: New Findings and Future Trends. Journal of Environmental Science and Allied Research, 2019, 85-90. https://doi.org/10.29199/2637-7063/ESAR-202024

[41] Ghernaout, D. (2019) Electrocoagulation and Electrooxidation for Disinfecting Water: New Breakthroughs and Implied Mechanisms. Applied Engineering, 3, 125-133.

[42] Lin, T., Li, L., Chen, W. and Pan, S.L. (2012) Effect and Mechanism of Preoxidation Using Potassium Permanganate in an Ultrafiltration Membrane System. Desalination, 286, 379-388. https://doi.org/10.1016/j.desal.2011.11.052

[43] Clancy, J.L., Bukhari, Z., Hargy, T.M., Bolton, J.R., Dussert, B.W. and Marshall, M.M. (2000) Using UV to Inactivate Cryptosporidium. Journal of the American Water Works Association, 92, 97-104. https://doi.org/10.1002/j.1551-8833.2000.tb09008.x

[44] Wang, J.L. and Xu, L.J. (2012) Advanced Oxidation Processes for Wastewater Treatment: Formation of Hydroxyl Radical and Application. Critical Reviews in Environmental Science and Technology 42, 251-325. https://doi.org/10.1080/10643389.2010.507698

[45] Ghernaout, D. and Naceur, M.W. (2011) Ferrate(VI): In Situ Generation and Water Treatment: A Review. Desalination and Water Treatment, 30, 319-332. https://doi.org/10.5004/dwt.2011.2217

[46] Ghernaout, D. and Elboughdiri, N. (2019) Mechanistic Insight into Disinfection Using Ferrate(VI). Open Access Library Journal, 6, e5946.

https://doi.org/10.4236/oalib.1105946

[47] Ghernaout, D. and Elboughdiri, N. (2019) Water Disinfection: Ferrate(VI) as the Greenest Chemical: A Review. Applied Engineering, 3, 171-180.

[48] Qi, C.D., Liu, X.T., Ma, J., Lin, C.Y., Li, X.W. and Zhang, H.J. (2016) Activation of Peroxymonosulfate by Base: Implications for the Degradation of Organic Pollutants. Chemosphere, 151, 280-288.

https://doi.org/10.1016/j.chemosphere.2016.02.089

[49] Chu, W.H., Chu, T.F., Bond, T., Du, E.D., Guo, Y.Q. and Gao, N.Y. (2016) Impact of Persulfate and Ultraviolet Light Activated Persulfate Pre-Oxidation on the Formation of Trihalomethanes, Haloacetonitriles and Halonitromethanes from the Chlor(am)ination of Three Antibiotic Chloramphenicols. Water Research, 93, 48-55. https://doi.org/10.1016/j.watres.2016.02.013

[50] Huang, K.C., Zhao, Z.Q., Hoag, G.E., Dahmani, A. and Block, P.A. (2005) Degradation of Volatile Organic Compounds with Thermally Activated Persulfate Oxidation. Chemosphere, 61, 551-560. https://doi.org/10.1016/j.chemosphere.2005.02.032

[51] Sarathy, S. and Mohseni, M. (2010) Effects of $\mathrm{UV} / \mathrm{H}_{2} \mathrm{O}_{2}$ Advanced Oxidation on 
Chemical Characteristics and Chlorine Reactivity of Surface Water Natural Organic Matter. Water Research, 44, 4087-4096. https://doi.org/10.1016/j.watres.2010.05.025

[52] Kleiser, G. and Frimmel, F.H. (2000) Removal of Precursors for Disinfection by-Products (DBPs)-Differences between Ozone and OH-Radical-Induced Oxidation. Science of the Total Environment, 256, 1-9. https://doi.org/10.1016/S0048-9697(00)00377-6

[53] Sarathy, S.R. and Mohseni, M. (2009) The Fate of Natural Organic Matter during $\mathrm{UV} / \mathrm{H}_{2} \mathrm{O}_{2}$ Advanced Oxidation of Drinking Water. Canadian Journal of Civil Engineering, 36, 160-169. https://doi.org/10.1139/S08-045

[54] Bae, S., Maestre, J.P., Kinney, K.A. and Kirisits, M.J. (2019) An Examination of the Microbial Community and Occurrence of Potential Human Pathogens in Rainwater Harvested from Different Roofing Materials. Water Research, 159, 406-413. https://doi.org/10.1016/j.watres.2019.05.029

[55] Kim, R.-H., Lee, S. and Kim, J.-O. (2005) Application of a Metal Membrane for Rainwater Utilization: Filtration Characteristics and Membrane Fouling. Desalination, 177, 121-132. https://doi.org/10.1016/j.desal.2004.12.004

[56] Ghernaout, D. and El-Wakil, A. (2017) Requiring Reverse Osmosis Membranes Modifications: An Overview. American Journal of Chemical Engineering, 5, 81-88. https://doi.org/10.11648/j.ajche.20170504.15

[57] Ghernaout, D. (2017) Reverse Osmosis Process Membranes Modeling: A Historical Overview. Journal of Civil, Construction and Environmental Engineering, 2, 112-122.

[58] Ghernaout, D., El-Wakil, A., Alghamdi, A., Elboughdiri, N. and Mahjoubi, A. (2018) Membrane Post-Synthesis Modifications and How It Came about. International Journal of Advances in Applied Sciences 5, 60-64. https://doi.org/10.21833/ijaas.2018.02.010

[59] Ait Messaoudene, N., Naceur, M.W., Ghernaout, D., Alghamdi, A. and Aichouni, M. (2018) On the Validation Perspectives of the Proposed Novel Dimensionless Fouling Index. International Journal of Advances in Applied Sciences, 5, 116-122. https://doi.org/10.21833/ijaas.2018.07.014

[60] Ghernaout, D., Alshammari, Y., Alghamdi, A., Aichouni, M., Touahmia, M. and Ait Messaoudene, N. (2018) Water Reuse: Extenuating Membrane Fouling in Membrane Processes. International Journal of Environmental Analytical Chemistry, 2, 1-12. https://doi.org/10.11648/j.ajche.20180602.12

[61] Ghernaout, D. (2019) Brine Recycling: Towards Membrane Processes as the Best Available Technology. Applied Engineering, 3, 71-84.

[62] Wurthmann, K. (2019) Assessing Storage Requirements, Water and Energy Savings, and Costs Associated with a Residential Rainwater Harvesting System Deployed across Two Counties in Southeast Florida. Journal of Environmental Management, 252, Article ID: 109673. https://doi.org/10.1016/j.jenvman.2019.109673

[63] Gikas, G.D. and Tsihrintzis, V.A. (2012) Assessment of Water Quality of First-Flush Roof Runoff and Harvested Rainwater. Journal of Hydrology, 466-467, 115-126. https://doi.org/10.1016/j.jhydrol.2012.08.020

[64] Nalwanga, R., Muyanja, C.K., McGuigan, K.G. and Quilty, B. (2018) A Study of the Bacteriological Quality of Roof-Harvested Rainwater and an Evaluation of SODIS as a Suitable Treatment Technology in Rural Sub-Saharan Africa. Journal of Environmental Chemical Engineering, 6, 3648-3655. https://doi.org/10.1016/j.jece.2016.12.008 